Original Article

\title{
Phytochemical screening of Cordia glabrata (MART.) A.DC. extracts and its potential antioxidant, photoprotective, antimicrobial and antiviral activities
}

\author{
Triagem fitoquímica de extratos de Cordia glabrata (MART.) A.DC. e sua potencial \\ atividade antioxidante, fotoprotetora, antimicrobiana e antiviral
}

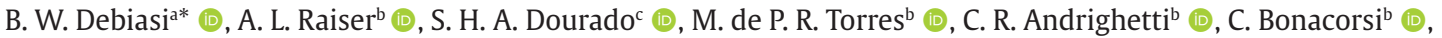 \\ L. D. Battirolad ${ }^{d}$, E. B. Ribeiro ${ }^{\mathrm{b}}$ (D) and D. M. S. Valladão ${ }^{\mathrm{b}}$ (D) \\ aUniversidade Federal do Mato Grosso - UFMT, Institute of Natural, Human and Social Sciences, Post Graduate Program in Environmental \\ Sciences - PPGCAM, Campus Sinop, Sinop, MT, Brasil \\ bUniversidade Federal do Mato Grosso - UFMT, Institute of Health Sciences, Campus Sinop, Sinop, MT, Brasil \\ 'Universidade Federal do Mato Grosso - UFMT, Institute of Health Sciences, Post Graduate Program in Health Sciences - PPGCS, Campus Sinop, \\ Sinop, MT, Brasil \\ dUniversidade Federal do Mato Grosso - UFMT, Institute of Natural, Human and Social Sciences, Campus Sinop, Sinop, MT, Brasil
}

\begin{abstract}
Species of the genus Cordia have shown biological activities, such as anti-inflammatory, analgesic, antioxidant, antiviral, and antifungal activities. The species Cordia glabrata (MART) A.DC. Has no information concerning its phytochemical profile and possible biological activities. Thus, this study aimed to evaluate this profile in ethanolic extracts of young, adult and senescent leaves, as well as their antioxidant, photoprotective, antimicrobial, and virucidal potentials. Phytochemical analysis was performed by TLC (thin-layer chromatography) and showed the presence of flavonoids, tannins, and terpenes. The evaluation by UPLC-MS/MS (Ultra performance liquid chromatography - tandem mass spectrometer) evidenced the presence of caffeic $\left(3.89 \mathrm{mgL}^{-1}\right), p$-cumaric $\left(6.13 \mathrm{mgL}^{-1}\right)$, and ferulic $\left(0.58 \mathrm{mgL}^{-1}\right)$ acids, whilst, in GC/MS (Gas chromatography-mass spectrometry) analysis there was a greater amount of palmitic (51.17\%), stearic (20.34\%), linoleic (9.62\%), and miristic $(8.16 \%)$ fatty acids. The DPPH (2,2-Diphenyl-1-picrylhydrazyl) and $\mathrm{ABTS}^{+}$(2'-Azino-bis(3-ethylbenzothiazoline-6-sulfonic acid)) radicals were used to verify the potential antioxidant activity, observing a better activity for the leaf extract in the adult phenological stage: $54.63 \pm 1.06 \mu \mathrm{gmL}^{-1}(\mathrm{DPPH})$ and $44.21 \pm 1.69 \mathrm{mM}$ (ABTS). The potential photoprotective activity of the extracts was determined by spectrophotometry and the in vitro values of SPF (Sun Protection Factor) in young and adult leaves (5.47 and 5.41, respectively) showed values close to the minimum SPF of 6.0 required by ANVISA (Brazilian Health Regulatory Agency). It was not observed an antimicrobial activity for Staphylococcus aureus with a minimum inhibitory concentration of $2000 \mathrm{\mu gmL}^{-1}$, however the anti-herpetic assay against the Herpes simplex virus type 2 (HSV-2) showed a potent virucidal activity at the tested concentrations with $\mathrm{CV}_{50}$ value $<0.195 \mu \mathrm{gmL}^{-1}$ and a Selectivity Index $\left(\mathrm{SI}=\mathrm{CC}_{50} / \mathrm{CV}_{50}\right)$ greater than 448 . The results obtained in this study suggest that extracts of leaves of $C$. glabrata in their adult phenological stage have potential antioxidant, photoprotective and virucidal activity, considering in vitro test results.
\end{abstract}

Keywords: chromatography, metabolites, HSV-2, HPLC, polyphenols.

\begin{abstract}
Resumo
Espécies do gênero Cordia apresentam atividades biológicas, como anti-inflamatória, analgésica, antioxidante, antiviral e antifúngica. Para a espécie Cordia glabrata (MART) A.DC., ainda não existem informações sobre seu perfil fitoquímico e possíveis atividades biológicas, deste modo, o presente estudo teve como objetivo avaliar este perfil em extratos etanólicos de folhas jovens, adultas e senescentes, bem como o potencial antioxidante, fotoprotetor, antimicrobiano e virucida. A análise fitoquímica foi realizada por CCD (Cromatografia em Camada Delgada), mostrando a presença de flavonóides, taninos e terpenos. Na avaliação por CLAE EM/EM (Cromatografia Líquida de Ultra Eficiência acoplada a Espectrometria de Massas) foi evidenciado a presença dos ácidos caféico $\left(3,89 \mathrm{mgL}^{-1}\right), p$-cumárico $\left(6,13 \mathrm{mgL}^{-1}\right)$ e ferúlico $\left(0,58 \mathrm{mgL}^{-1}\right)$, paralelamente, na CG/EM (Cromatografia Gasosa acoplada a Espectrometria de Massas) verificou-se maior quantidade dos ácidos graxos palmítico (51,17\%), esteárico (20,34\%), linoléico (9,62\%) e mirístico (8,16\%). Os radicais DPPH (2,2-Difenil-1-picrilhidrazil) e ABTS ${ }^{+}$(2'-Azino-bis (ácido 3-etilbenzotiazolina-6-sulfônico)) foram utilizados para verificar o potencial antioxidante, observandose uma atividade superior para o extrato da folha em sua fase fenológica adulta: $54,63 \pm 1,06 \mu \mathrm{gmL}^{-1}(\mathrm{DPPH}) \mathrm{e}$
\end{abstract}

*e-mail: dbryanwender@gmail.com

Received: January 28, 2021 - Accepted: March 24, 2021

This is an Open Access article distributed under the terms of the Creative Commons Attribution License, which permits unrestricted use, distribution, and reproduction in any medium, provided the original work is properly cited. 


\begin{abstract}
$44,21 \pm 1,69 \mathrm{mM}\left(\mathrm{ABTS}^{+}\right)$. A potencial atividade fotoprotetora dos extratos foi determinada espectrofotometricamente e os valores in vitro de FPS (Fator de Proteção Solar) em folhas jovens e adultas (5,47 e 5,41 respectivamente) apresentaram valores próximos ao FPS mínimo de 6,0 exigido pela ANVISA (Agência Nacional de Vigilância Sanitária). Não foi observada atividade antimicrobiana para Staphylococcus aureus sendo a concentração inibitória mínima de $2000 \mathrm{\mu gmL}^{-1}$, no entanto o ensaio anti-herpético contra o vírus Herpes simplex tipo 2 (HSV-2) mostrou uma potente atividade virucida nas concentrações testadas com um valor de $\mathrm{CV}_{50}<0,195 \mu \mathrm{gmL}^{-1}$ e um Índice de Seletividade (IS $=\mathrm{CC}_{50} / \mathrm{CV}_{50}$ ) maior que 448. Os resultados obtidos neste estudo sugerem que extratos de folhas de $C$. glabrata em seu estágio fenológico adulto apresentam potencial antioxidante, fotoprotetora e virucida, considerando os resultados de testes in vitro.
\end{abstract}

Palavras-chave: cromatografia, metabólitos, HSV-2, CLAE, polifenóis.

\section{Introduction}

Plants are a stand out for providing substances with potential biological activity from their secondary metabolism (Tanase et al., 2019). Factors such as seasonality, temperature, water availability, nutrients, air pollution, mechanical stimuli, and attacks by pathogens, herbivores, and insects can influence the concentration and/or constitution of these metabolites (Botrel et al., 2010; Vizzotto et al., 2010). Furthermore, the discovery and supply of secondary metabolites with potential biological activity bring about great interest for the development of new products by the pharmaceutical, cosmetic, food, and agrochemical industries (Jaradat et al., 2018; MoreiraAraújo et al., 2019).

The species Cordia glabrata is a plant that belongs to the genus Cordia Linnaeus and the Boraginaceae Family, which is distributed from Central America to the central region of Argentina (IPNI, 1845; Vieira et al., 2015).

Some ethanolic leaf extracts of some species from this genus present biological activities, such as Cordia verbenacea and Cordia curassavica with anti-inflammatory and analgesic activity (Lameira et al., 1997; Bayeux et al., 2002), Cordia boissieri and Cordia sinensis Lam. with antioxidant activity (Al-Musayeib et al., 2011; Salazar-Aranda et al., 2011), and Cordia dichotoma and Cordia verbenacea with antimicrobial and antifungal activity (Matias et al., 2016; Pinho et al., 2012; Rahman and Akhtar 2016).

The species Cordia glabrata (Mart.) A.DC., popularly known as "louro-branco", "claraíba", "louro-de-matogrosso" and "peteribi", occurring from the Piauí to the Northeast of Mato Grosso do Sul state, mostly concentrated in the Pantanal and Cerrado (Brazilian Savannah) regions of Mato Grosso - Brazil (Vieira et al., 2015; Moulin et al., 2016), there are still no reports on the species phytochemical profile, and its possible biological activities.

Thus, this work aimed to analyze the phytochemical profile and evaluate the potential antioxidant, photoprotective, virucidal and antimicrobial activity of the species C. glabrata.

\section{Material and Methods}

\subsection{Plant Material obtention}

The collection was carried out in an area from the Cerrado (Brazilian Savannah) of Mato Grosso - Brazil, at the Federal University of Mato Grosso - UFMT, Campus of Cuiabá (56 $06^{\circ} 44.6^{\prime \prime} 015^{\circ} 36^{\prime} 30.5^{\prime \prime}$ ). Four collections in one individual of $C$. glabrata were performed in the period between January and December 2019, during two seasonal periods of the region (rainy - October to April - and dry season - may to september) (Heckman, 1998), covering the entire plant phenological cycle. The botanical identification was performed at the Centro-Norte-MatoGrossense Herbarium (CNMT) from the Federal University of Mato Grosso, Campus of Sinop, where the plant's and a exsiccate was stored under the registration number CNMT 7364 and code A3AE708 at Sistema Nacional de Gestão do Patrimônio Genético e do Conhecimento Tradicional Associado (SisGen).

The collected plant material was sent to the Quality Control laboratory at UFMT, Campus of Sinop, where they were examined and selected, discarding material presenting fungi or injuries caused by insects and/or environmental factors. Later, the material was dried in a forced convection drying oven at a temperature of $40 \pm 1^{\circ} \mathrm{C}$, for 48 hours. After dried, the material was ground in a mill and stored at room temperature sheltered from light.

\subsection{Extracts obtention}

The plant material was submitted to extraction by cold maceration with absolute ethanol (EtOHa) in the proportion of $1: 4(\mathrm{~m} / \mathrm{v})$, at room temperature in a seven days cycle, with manual stirring every 24 hours. After the period of seven days the solvent was eliminated in a rotary evaporator, providing the crude ethanolic extracts. The extracts were weighed for extraction yield evaluation and then stored in properly closed bottles protected from light and refrigerated.

\subsection{Reagents}

All reagents and solvents used in the analyzes were analytical grade. Ethyl alcohol, methyl alcohol, aluminum chloride $\left(\mathrm{AlCl}_{3}\right)$, and sodium carbonate $\left(\mathrm{Na}_{2} \mathrm{CO}_{3}\right)$ were supplied by Synth (Diadema, SP, Brazil) and the FolinCiocateau solution by Dinâmica (Indaiatuba, SP, Brazil). Ethyl acetate, methanol, formic acid, gallic acid, caffeic acid, p-cumaric acid, ferulic acid, quercetin, apigenin, kaempferol, pinocembrin, pinobanksin, 2,2-diphenyl-1-picrylhydrazyl (DPPH), 2,2'-azino-bis(3-ethylbenzothiazoline-6-sulfonic acid) (ABTS ${ }^{\mathrm{TM}}$ ), 6-hydroxy-2,5,7,8-tetramethyl chroman-2carboxylic acid (Trolox $\left.{ }^{\mathrm{TM}}\right), 3$-(4,5-dimethyl-2-thiazolyl)-2, 5-diphenyl-2H-tetrazolium bromide (MTT), naphthalene black, dimethyl sulfoxide (DMSO), Leibovitz-15 (L-15), fetal bovine serum (FBS), Penicillin G, streptomycin and amphotericin B were purchased from Sigma Aldrich Co. (St. 
Louis, MO, USA). The Mueller Hinton M173 and M391 broths were purchased from Himedia (Mumbai, India).

\subsection{Phytochemical screening by thin-layer chromatography (TLC)}

Phytochemical screening was performed by thin-layer chromatography (TLC) according to Wagner and Bladt (2001), using silica gel 60 plates containing fluorescein (Chromatoplate Alugram ${ }^{\circledR}$ Xtra SIL G / UV254) as stationary phase, and different mobile phases, with different polarities. The visualization was performed using ultraviolet radiation 254-365 nm and chemical reagents for each class of metabolites (Wagner and Bladt, 2001; Simões et al., 2010).

\subsection{Determination of total phenolic compounds}

The determination of total phenolic compounds was performed using the Folin-Ciocalteau spectrophotometric method according to Roesler et al. (2007). The extracts were prepared in methanol $(\mathrm{MeOH})$ at a concentration of $500 \mu \mathrm{gmL}^{-1}$ and then diluted in order to obtain concentrations from 50 to $150 \mu \mathrm{gmL}^{-1}$. $1000 \mu \mathrm{L}$ of each sample was transferred to a screw-cap test tube with $5 \mathrm{~mL}$ of distilled water, $1000 \mu \mathrm{L}$ of the Folin-Ciocalteu reagent, and $1000 \mu \mathrm{L}$ of a $7.5 \%$ sodium carbonate $\left(\mathrm{Na}_{2} \mathrm{CO}_{3}\right)$ solution. The samples were homogenized and sheltered from light for one hour. The tests were performed in triplicate and the absorbance reading was done on a spectrophotometer at a wavelength of $750 \mathrm{~nm}$. A blank test was performed to correct the absorbance measurements.

To prepare the calibration curve, gallic acid was used in concentrations from 10 to $100 \mu \mathrm{gmL}^{-1}$. The total phenolic values were expressed as gallic acid equivalent (milligram of gallic acid equivalent per gram of extract - mgEAG. ${ }^{-1}$ and microgram of gallic acid equivalent per $\mathrm{ml}$ of extract $\mu \mathrm{gmL}^{-1}$ ) (Neves et al., 2009; Santi et al., 2014).

\subsection{Determination of total flavonoids}

The determination of total flavonoids from the extracts was performed through the reaction with aluminum chloride $\left(\mathrm{AlCl}_{3}\right)$, and using quercetin as a standard according to the methodology described by Silva et al. (2017). The extracts were solubilized in EtOHa to a concentration of $1000 \mu \mathrm{gmL}^{-1}$ and from these solutions, dilutions were made in EtOHa to concentrations of 50 to $150 \mathrm{\mu gmL}^{-1}$. From each sample, 500 to $1500 \mu \mathrm{L}$ aliquots were transferred to $10 \mathrm{~mL}$ volumetric flasks, then $2 \mathrm{~mL}$ of a $5.0 \% \mathrm{AlCl}_{3}$ solution was added to each flask, and the volume was completed with EtOHa. The samples were homogenized and left to rest sheltered from light for 30 minutes, all of them performed in triplicate. The absorbance of the samples was determined in a spectrophotometer at a wavelength of $425 \mathrm{~nm}$. A blank test was performed to correct the absorbance measurements and a calibration curve was prepared using quercetin as a standard, in concentrations from 3.0 to $9.0 \mu \mathrm{gmL}^{-1}$. Values were expressed as quercetin equivalent (milligram of quercetin equivalent per gram of extract - mgEQ. $\mathrm{g}^{-1}$ and microgram of quercetin equivalent per $\mathrm{ml}$ of extract $-\mu g \mathrm{~mL}^{-1}$ ).
2.7. Determination of phenolic compounds by Ultraefficient Liquid Chromatography coupled to Mass Spectrometry (UPLC-MS/MS)

The analysis was performed by a UPLC-MS/MS system (Agilent 1290 Infinity with triple quadrupole Agilent 6460) in multiple reaction monitoring (MRM) mode. The ethanolic adult leaves extracts were dissolved in ethyl acetate and diluted to a concentration of $2.0 \mathrm{mgmL}^{-1}$. The UPLC-MS/ MS analysis used the $\mathrm{C}-18$ silica gel column as stationary phase (Zorbax Eclipse AAA 4.6 x $150 \mathrm{~mm}, 3.5 \mu \mathrm{m}$ particle size, Agilent, Santa Clara - CA, United States). The mobile phase consisted of the solvents: $\mathrm{A}(\mathrm{MeOH}+0.1 \%$ formic acid), and B (Milli-Q water $+0.1 \%$ formic acid), with an injection flow of $0.3 \mathrm{~mL} \cdot \mathrm{min}^{-1}$. The initial elution gradient consisted of $60 \%$ (A) and 40\% (B), increasing linearly to $90 \%$ of $A$ for 10 minutes, $90 \%$ of $A$ in isocratic mode for 3 minutes, decreasing linearly to $60 \%$ of A during 2 minutes and ending with $60 \%$ of $\mathrm{A}$ isocratically for 4 minutes. The extracts were detected by mass spectrometry using electrospray ionization in the negative mode. The gradient elution method of the sample had a source temperature of $300^{\circ} \mathrm{C}$ and a desolvation temperature of $250{ }^{\circ} \mathrm{C}$. The results were compared to the standards (gallic acid, caffeic acid, p-cumaric acid, ferulic acid, quercetin, apigenin, kaempferol, pinocembrin, pinobanksina).

\subsection{Determination of fatty acids by Gas Chromatography coupled to Mass Spectrometry (GC-MS)}

The C. glabrata leaves extract was esterified according to Jham et al. (1982). The fatty acid composition of the extract was determined in a gas chromatograph (Shimadzu - GCMS-QP2010 Ultra) connected to a mass spectrometer (QP2010 Ultra), using helium as the carrier gas $\left(1.0 \mathrm{mLmin}^{-1}\right)$ under the following conditions: $1 \mu \mathrm{L}$ of sample injection volume; Split 3: 1; column: HP-5MS (30m x 0,25mm) packed with (5\%-phenyl)-methylpolysiloxane; MS source: $230^{\circ} \mathrm{C}$; Quad MS: $150^{\circ} \mathrm{C}$; gradient: $140^{\circ} \mathrm{C}$ ( 2 minutes $)$, $4{ }^{\circ} \mathrm{Cmin}^{-1}$ to $180{ }^{\circ} \mathrm{C}, 0.5^{\circ} \mathrm{Cmin}^{-1}$ to $200{ }^{\circ} \mathrm{C}, 5^{\circ} \mathrm{Cmin}^{-1}$ to $250^{\circ} \mathrm{C}$ ( 3 minutes); Full time: 70 minutes. Fatty acids were identified based on the retention time of the standard (Lipid Standards Sigma-Aldrich: FAMEs mixtures C8:0 - C22:0), injected under the same conditions.

\subsection{Evaluation of potential antioxidant activity by the DPPH (2,2-diphenyl-1-picrylhydrazyl) radical scavenging method}

The potential antioxidant activity by the DPPH radical scavenging method was carried out as described by Rufino et al. (2007) and Pires et al. (2017). The extract solutions were prepared at a concentration of $4000 \mu \mathrm{gmL}^{-1}$ and diluted with ethanol to concentrations of 8.0 to $400 \mu \mathrm{gmL}^{-1}$. $1000 \mu \mathrm{L}$ of each sample was transferred to screw-cap test tubes and $3 \mathrm{ml}$ of the DPPH radical solution was added. The samples were homogenized and, after a period of 30 minutes in the absence of light, the absorbance was read at a wavelength of $517 \mathrm{~nm}$. The tests were performed in triplicate and a blank test was performed to correct the absorbance measurements. The results were expressed as $\mathrm{EC}_{50}$, which is the extract concentration needed to reduce $50 \%$ of DPPH. 


\subsection{Evaluation of the potential antioxidant activity by} the ABTS method (2,2'-azino-bis(3-ethylbenzothiazoline6-sulfonic acid)

The ABTS radical scavenging method was performed as described by Rufino et al. (2007). The extract solutions were prepared with absolute ethanol (EtOHa) at a concentration of $1000 \mu \mathrm{gmL}^{-1}$ and then diluted with etanol to concentrations from 300 to $1000 \mu \mathrm{gmL}^{-1}$. $30 \mu \mathrm{L}$ of the solutions and $3 \mathrm{~mL}$ of the ABTS radical solution were transferred to screw-cap test tubes, then the mixture was homogenized and left to rest sheltered from light for six minutes. All analyzes were performed in triplicate and a blank test was performed to correct the absorbance measurements. The absorbance reading was performed at a wavelength of $734 \mathrm{~nm}$.

A calibration curve was prepared with Trolox (6-hydroxy-2,5,7,8-tetramethyl chroman-2-carboxylic acid) in concentrations of 100 to $2000 \mu \mathrm{M}$. The potential antioxidant activity was calculated in relation to the Trolox activity, and the results are expressed in $\mu \mathrm{M}$ of Trolox.g-1 of leaves

\subsection{In vitro determination of the SPF}

The in vitro sun protection factor (SPF) for C. glabrata extracts was determined according to the protocol established by Mansur et al. (1986). The leaves extracts solutions used to determine the SPF were prepared at a concentration of $200 \mu \mathrm{gmL}^{-1}$ in EtOHa. The equation that establishes the SPF is given by:

$$
320
$$$$
S P F=F C . \sum E E(\lambda) \cdot 2 . I(\lambda) \cdot A b s(\lambda)
$$

290

Where: $\mathrm{CF}=$ correction factor (equal to 10$)$; $\mathrm{EE}(\lambda)=$ erythematogenic effect of the wavelength $\lambda$ radiation; I $(\lambda)=$ sunlight intensity at the wavelength $\lambda$; Abs $(\lambda)=$ spectrophotometric reading of the solution absorbance at the wavelength $(\lambda)$.

\subsection{Evaluation of potential antimicrobial activity}

Strains of Staphylococcus aureus (ATCC 25923) were used for the assay. The potential antimicrobial activity was performed using the broth microdilution technique following the recommendations from the Clinical and Laboratory Standards Institute - CLSI (2018, 2020). The minimum inhibitory concentration (MIC) was defined as the lowest concentration of the extract capable of reducing microbial growth by $\geq 90 \%$ compared to the control growth.

Microplates containing 96 wells were used to perform the assay, they were filled with $100 \mu \mathrm{L}$ of Mueller Hinton broth containing different concentrations of the leaves extracts (62.5-2000 $\left.\mu \mathrm{gmL}^{-1}\right)$ and the same volume of bacterial suspension containing $106 \mathrm{CFUmL}^{-1}$ in broth Mueller Hinton (after inoculation, each well had approximately $5 \times 105 \mathrm{CFUmL}^{-1}$ ) was added. The microplate was incubated at $36 \pm 1^{\circ} \mathrm{C}$, aerobically for 24 hours. After incubation, the plate was homogenized and read in a spectrophotometer at $630 \mathrm{~nm}$. Bacterial growth control was also performed. All tests were performed in triplicate.
2.13. Evaluation of the potential antiviral activity against Herpes simplex virus type 2 (HSV-2)

\subsubsection{Preparation of the extract for analysis}

The extract of $C$. glabrata was dissolved in dimethyl sulfoxide (DMSO) at a concentration of $10,000 \mu \mathrm{gmL}^{-1}$, stored at $-20{ }^{\circ} \mathrm{C}$ and diluted in culture medium at the time of use, not exceeding the concentration of $1 \%$ DMSO.

\subsubsection{Cells and viruses}

Vero E6 cells were cultivated in Leibovitz-15 (L-15) medium supplemented with $5 \%$ fetal bovine serum (FBS), penicillin G (100 UmL-1), streptomycin (100 $\mu \mathrm{gmL}-1)$, and amphotericin B $(25 \mu \mathrm{gmL}-1)$. Cell cultures were maintained at $37{ }^{\circ} \mathrm{C}$. The HSV-2 virus strain 333 (Department of Clinical Virology, University of Gotebörg, Sweden) was propagated in Vero E6 cells. The viral titer was determined by the plate reduction method (Burleson et al., 1992) and expressed through the number of plaque-forming units per $\mathrm{ml}\left(\right.$ PFUmL $\left.\mathrm{m}^{-1}\right)$. All analyzes were performed in triplicate.

\subsubsection{Evaluation of cytotoxicity}

The cytotoxicity of the samples was determined by the [3- (4,5-dimethylthiazol-2-yl) -2,5-diphenyltetrazolium bromide] (MTT) assay (Mosmann, 1983). Vero E6 cell suspensions containing approximately $1.8 \times 10^{5}$ cells per $\mathrm{ml}$ were distributed in 96 well plates $(100 \mu \mathrm{L}$ per well $)$ and incubated for $24 \mathrm{~h}$ at $37^{\circ} \mathrm{C}$. After this period, the medium was removed from the plate and $200 \mu \mathrm{L}$ of different dilutions of the extracts ( 100 to $0.78 \mu \mathrm{gmL}^{-1} ; 1$ : 2 ratio) were added to the cells. Cell control was performed on the same plate (200 $\mu \mathrm{L}$ medium in each well). The plates were incubated for $48 \mathrm{~h}$ at $37^{\circ} \mathrm{C}$. After this period, the medium was replaced by $50 \mu \mathrm{L}$ of MTT ( $1 \mathrm{mgmL}^{-1}$ in L- 15 medium) and the plates were incubated for 4 hours. The MTT solution was removed, $100 \mu \mathrm{L}$ of DMSO was added to each well, the plate was shaken for $10 \mathrm{~min}$ on a plate shaker and the absorbance was read at $492 \mathrm{~nm}$. The extract concentration value capable of reducing cell viability by $50 \%\left(\mathrm{CC}_{50}\right)$ in relation to cell control was calculated by linear regression analysis.

\subsubsection{In vitro screening for anti-HSV-2 activity}

The suspensions of Vero E6 cells $\left( \pm 1.8 \times 10^{5}\right.$ cells per $\mathrm{ml}$ ) were distributed in 96 well plates and incubated for $24 \mathrm{~h}$ at $37^{\circ} \mathrm{C}$. After this period, the medium was removed from the plate and the monolayer of Vero E6 cells was infected with the HSV-2 virus (0.05 MOI) and simultaneously treated with four different concentrations of the extract for $48 \mathrm{~h}$. Acyclovir $(15 \mu \mathrm{M})$ was used as a positive control for inhibition of HSV-2 strain 333. The same method described above was used to assess cell viability with MTT. The inhibition percentages were calculated using the formula [(A-B) / (C-B) X100], where A, B and C indicate the extract, the viral and the cellular control absorbances, respectively.

\subsubsection{Evaluation of the virucidal activity}

Mixtures of $200 \mu \mathrm{l}$ of different concentrations of the extracts (50 to $0.195 \mu \mathrm{gmL}^{-1}$ ) and $200 \mu \mathrm{l}$ of the viral 
suspension (25-50 PFU) were mixed and incubated at $37^{\circ} \mathrm{C}$ for 30 minutes. After this time, the residual infectivity of these suspensions was determined by the plate reduction assay. Therefore, Vero E6 cells $\left(1.8 \times 10^{5}\right.$ cells per $\left.\mathrm{mL}\right)$ cultivated in 24-well plates until confluence were infected with $400 \mu \mathrm{L}$ of the viral suspension and incubated for $1 \mathrm{~h}$ at $37^{\circ} \mathrm{C}$. After removing the supernatant, $1 \mathrm{ml}$ of the $1.5 \%$ carboxymethyl cellulose solution in L-15 medium was added. Untreated wells were used as infection controls. The plates were incubated for 2 days at $37^{\circ} \mathrm{C}$. After this period, the medium was removed and the cells were stained with $600 \mu \mathrm{L}$ of $1 \%$ naphthalene black for 1 hour under mechanical stirring at room temperature. The percentages of residual infectivity of the extract were calculated in relation to the infection control. From these data, it was possible to calculate the concentration that reduces viral infectivity by $50 \%\left(\mathrm{CV}_{50}\right)$ by linear regression analysis.

\subsection{Statistical analysis}

The determination of total phenolic and flavonoid compounds, the antioxidant activity analyzes by the ABTS and DPPH methods, and the virucide and antimicrobial methods were compared by analysis of variance (ANOVA). Significant differences between the mean values were determined by Tukey's multiple comparison test with $95 \%$ significance $(\mathrm{p}<0.05)$ and the results were presented with the mean \pm standard deviation using the OriginPro program, v 8 (OriginLab $\left.{ }^{\odot}\right)$. The correlation coefficient was determined by the Pearson test, using the Microsoft Excel ${ }^{\circledR} 2016$ program.

\section{Results}

Two collections were carried out during the rainy season, with the presence of young and adult leaves, and only one in the dry season, during the presence of senescent leaves, before seasonal leaf fall and flower development. Therefore, the phenological stages of the plant are young and adult leaves during the rainy season, senescent leaves and flower blossoming in the dry season.

The yield values were obtained from the relation between the crude leaves extracts and the previously weighed masses of the plant materials. The young leaves extract showed the lowest yield, followed by an increase for adult leaves and a subsequent decrease in senescent leaves (Table 1 ).

The phytochemical screening of leaves extracts as shown in Table 2 showed the presence of metabolites derived from phenolic compounds, such as flavonoids, tannins, and terpenes.

In the determination of phenolic compounds tests, the adult leaves extract showed a higher concentration $\left(89.11 \pm 0.46\right.$ mgEAG. $\left.^{-1}\right)$ followed by senescent leaves $\left(79.07 \pm 0.60\right.$ mgEAG. $\left.^{-1}\right)$ and young leaves $(65.11 \pm$ 1.52 mgEAG. $^{-1}$ ). The same tendency was observed for the flavonoids, that is, higher content in the adult leaves extract $\left(15.37 \pm 0.11 \mathrm{mgEQ} . \mathrm{g}^{-1}\right)$, followed by young leaves $\left(14.30 \pm 0.11 \mathrm{mgEQ} \cdot \mathrm{g}^{-1}\right)$ and senescent leaves $(12.03 \pm$ $0.01 \mathrm{mgEQ}^{-1}{ }^{-1}$ ) (Table 3).
In order to quantify some phenolic compounds and fatty acids present in the adult leaves of $C$. glabrata (because it is the phenological stage with the highest content of these metabolites), liquid and gas chromatography (UPLC-MS/ MS and GC/MS) were performed. The values obtained by UPLC-MS/MS for the nine compounds analised are shown in Table 4.

The concentrations of gallic acid, quercetin, apigenin, kaempferol, pinocembrin, and pinobanksin were below the detection limit of the method.

Table 5 shows the fatty acids determined for C. glabrata by GC/MS, where there was a greater abundance of palmitic acid, comprising $51.17 \%$ of the total, followed by stearic acid (20.34\%), linoleic acid (9.62\%) and myristic acid (8.16\%).

The potential antioxidant activity of the extracts was assessed using the DPPH and $\mathrm{ABTS}^{+}$radical scavenging methods and results are shown in Table 6. For the DPPH method, the ethanolic extract of adult leaves $\mathrm{EC}_{50}$ values showed greater antioxidant potential $\left(49.79 \pm 0.47 \mu \mathrm{gmL}^{-1}\right)$, followed by young leaves $\left(54.63 \pm 1.06 \mu \mathrm{gmL}^{-1}\right)$ and senescent leaves $\left(58.09 \pm 0.39 \mu \mathrm{gmL}^{-1}\right)$. For the $\mathrm{ABTS}^{+}$radical scavenging method, the young leaves extract showed less potential antioxidant activity $(44.21 \pm 1.69 \mathrm{mM})$ when compared to the other leaves phenophases. The extracts of adult leaves $(55.40 \pm 0.616 \mathrm{mM})$ and senescent leaves $(57.93 \pm 3.56 \mathrm{mM})$ showed no statistical difference between them ( $\mathrm{p}<0.05$ ).

When the Pearson's correlation was performed, a strong positive correlation was found between the amount of phenolic compounds and flavonoids. The evaluation by the DPPH method showed a strong negative correlation between the method and the concentration of phenolic compounds, as well as for flavonoids. As for the relation between phenolic compounds and the $\mathrm{ABTS}^{+}$method, the correlation was positive and moderate, and between the $\mathrm{ABTS}^{+}$method and the concentration of flavonoids the correlation was positive and weak. The moderate negative correlation observed between the $\mathrm{ABTS}^{+}$and DPPH methods (Table 7).

The SPF values found for the extracts from Equation 1 showed a significant difference by the Tukey test ( $p<0.05$ ), presenting an SPF of $5.47 \pm 0.00$ for young leaves, $5.41 \pm 0.00$ for adults, and $4.10 \pm 0.00$ for the senescent leaves.

Several species of the Cordia genus have promising biological activities, such as antimicrobial and antiviral (Matias et al., 2015). For the potential antimicrobial activity, no significant activity was observed for extracts of the C. glabrata adult leaves. The value for the minimum inhibitory concentration (MIC) of the analyzed extract was $2000 \mu \mathrm{gmL}^{-1}$ for the Staphylococcus aureus strain that was tested (Table 8).

The analysis of the potential anti-HSV-2 activity of the C. glabrata adult leaves extract through the MTT assay showed a cytotoxicity of $\mathrm{CC}_{50}=87.43 \pm 17.26 \mu \mathrm{gmL}^{-1}$ against Vero E6 cells, and presented $29.98 \pm 5.82 \%$ of replication inhibition of the HSV-2 strain 333, at the maximum nontoxic concentration of $50 \mu \mathrm{gmL}^{-1}$ by the same assay (Table 9 ).

In addition, the adult leaves extract was subjected to evaluation of virucidal activity, through the plate reduction assay. The adult leave extract showed a potent virucidal action at the tested concentrations, with a $\mathrm{CV}_{50}$ value $<0.195 \mu \mathrm{gmL}^{-1}$ and a Selectivity Index $\left(\mathrm{SI}=\mathrm{CC}_{50} / \mathrm{CV}_{50}\right)$ greater than 448 (Figure 1). 
Table 1. C. glabrata crude extract yield in different phenological stages.

\begin{tabular}{cccc}
\hline & & EtOHa extracts & SL \\
\cline { 2 - 4 } & YL & AL & 50 \\
\hline Plant material weight (g) & 50 & 50 & 0.577 \\
Extract weight (g) & 0.574 & 0.681 & $1.154^{\mathrm{c}}$ \\
Yield (\%) & $1.148^{\mathrm{a}}$ & $1.362^{\mathrm{b}}$ & \\
\hline
\end{tabular}

$\overline{(E t O H a) ~ a b s o l u t e ~ e t h a n o l ; ~(Y L) ~ Y o u n g ~ L e a v e s ; ~(A L) ~ A d u l t ~ L e a v e s ; ~(S L) ~ S e n e s c e n t ~ L e a v e s . ~ V a l u e s ~ w i t h ~ d i f f e r e n t ~ l e t t e r s ~ d e m o n s t r a t e ~ s t a t i s t i c a l ~ d i f f r e n c e ~}(\mathrm{p}<0.05)$.

Table 2. Phytochemical screening of the C. glabrata extracts.

\begin{tabular}{ccccc}
\hline \multirow{2}{*}{ Phytochemical classes } & Reactions & \multicolumn{3}{c}{ EtOHa extracts } \\
\cline { 3 - 5 } Flavonoids & TLC & YL & AL & SL \\
Tannins & TLC & + & + & + \\
Terpenes & TLC & + & + & + \\
Coumarins & TLC & + & - & - \\
& KOH & - & - & - \\
Saponines & TLC & - & - & - \\
& Foam index & - & - & - \\
Alkaloids & TLC & - & - & - \\
& Dragendorf & - & - & - \\
Anthraquinones & Mayer & - & - & - \\
\hline
\end{tabular}

(EtOHa) absolute ethanol; (YL) Young Leaves; (AL) Adult Leaves; (SL) Senescent Leaves; (+) Presence of the metabolite; (-) Absence of the metabolite.

Table 3. Phenolic compounds and total flavonoids concentrations in the ethanolic extracts of $C$. glabrata leaves and flowers.

\begin{tabular}{|c|c|c|c|c|}
\hline \multirow{2}{*}{ Codes } & Phenols & Phenols & Flavonoids & Flavonoids \\
\hline & (mgEAG.g-1) & $\left(\mu \mathrm{gmL}^{-1}\right)^{*}$ & $\left(\mathrm{mgEQ} \cdot \mathrm{g}^{-1}\right)$ & $\left(\mu \mathrm{gmL}^{-1}\right)^{* *}$ \\
\hline $\mathbf{Y L}$ & $91.16 \pm 1.39^{\mathrm{a}}$ & $22.79 \pm 0.35^{\mathrm{d}}$ & $6.81 \pm 0.03^{g}$ & $10.22 \pm 0.04$ \\
\hline AL & $104.17 \pm 0.74^{b}$ & $26.04 \pm 0.18^{\mathrm{e}}$ & $6.86 \pm 0.01^{\mathrm{h}}$ & $10.30 \pm 0.02^{k}$ \\
\hline SL & $68.51 \pm 1.95^{c}$ & $17.13 \pm 0.48^{\mathrm{f}}$ & $3.90 \pm 0.00^{\mathrm{i}}$ & $5.85 \pm 0.00^{1}$ \\
\hline
\end{tabular}

$\left(\mathrm{mgEAG} . \mathrm{g}^{-1}\right)$ milligram of gallic acid equivalent per gram of extract; $\left(\mathrm{mgEQ} . \mathrm{g}^{-1}\right)$ milligram of quercetin equivalent per gram of extract; $\left(\mu \mathrm{gmL} \mathrm{L}^{-1}\right)$; ${ }^{*}$ microgram of gallic acid equivalent per $\mathrm{mL}$ of extract; $\left(\mu \mathrm{gmL}^{-1}\right) ;{ }^{* *}$ microgram of quercetin equivalent per $\mathrm{mL}$ of extract; (YL) Young Leaves;

(AL) Adult Leaves; (SL) Senescent Leaves. Values with different letters demonstrate statistical diffrence $(p<0.05)$.

Table 4. UPLC-MS/MS quantification of phenolic compounds in adult leaves of C. glabrata.

\begin{tabular}{|c|c|c|c|c|}
\hline Peak No. & Compound & RT (min.) & Transitions Ions & $\begin{array}{l}\text { Amount in the adult } \\
\text { leav extract }\left(\mathrm{mg} \mathrm{L}^{-1}\right)\end{array}$ \\
\hline 1 & Gallic acid ${ }^{a}$ & 4.8 & $168.7-124.7$ & $<$ L.Q \\
\hline 2 & Caffeic acid ${ }^{a}$ & 5.7 & $178.7-134.7$ & 3.89 \\
\hline 3 & $P$-cumaric acid ${ }^{a}$ & 6.5 & $162.7-118.7$ & 6.13 \\
\hline 4 & Ferulic acid ${ }^{a}$ & 7.8 & $192.9-133.9$ & 0.58 \\
\hline 5 & Quercetin $^{\mathrm{a}}$ & 9.5 & $284.9-116.8$ & $<$ L.Q \\
\hline 6 & Kaempferol $^{\mathrm{a}}$ & 11 & $284.9-92.9$ & $<$ L.Q \\
\hline 7 & Apigenin ${ }^{\mathrm{a}}$ & 11.5 & $269-116.7$ & $<$ L.Q \\
\hline 8 & Pinobanksin ${ }^{\mathrm{a}}$ & 10 & $272.7-226.8$ & $<$ L.Q \\
\hline 9 & Pinocembrin ${ }^{\mathrm{a}}$ & 13.5 & $256.7-152.9$ & $<$ L.Q \\
\hline
\end{tabular}

aBased on standart; (L.Q) Value below the quantification limit of the method $\left(0.1 \mathrm{mgL}^{-1}\right)$ 
Table 5. Fatty acid quantification in the C. glabrata ethanolic extract.

\begin{tabular}{lccc}
\hline & FATTY ACID & Area & Adult Leaves \\
\cline { 3 - 4 } & & 15681 & 0.12 \\
$\mathbf{1}$ & Capric acid & 50763 & 0.39 \\
$\mathbf{3}$ & Lauric acid & 1050174 & 8.16 \\
$\mathbf{4}$ & Myristic acid & 111659 & 0.87 \\
$\mathbf{5}$ & Palmitoleic acid & 6582208 & 51.17 \\
$\mathbf{6}$ & Palmitic acid & 1237771 & 9.62 \\
$\mathbf{7}$ & Linoleic acid & 362694 & 2.82 \\
$\mathbf{8}$ & Oleic acid & 2615964 & 20.34 \\
$\mathbf{9}$ & Stearic acid & 399612 & 3.11 \\
$\mathbf{1 0}$ & Arachidic acid & 297 & N.D. \\
$\mathbf{1 1}$ & Erucic acid & 524 & N.D. \\
\end{tabular}

(N.D.) Not detected.

Table 6. C. glabrata ethanolic extracts antioxidants activity through DPPH and ABTS+ radical scavenging methods.

\begin{tabular}{ccc}
\hline Codes & EC $_{50}\left(\mu \mathbf{g m L}^{-1}\right)$ & ABTS $(\mathbf{m M})$ \\
\hline YL & $54.63 \pm 1.06^{\mathrm{a}}$ & $44.21 \pm 1.69^{\mathrm{a}}$ \\
AL & $49.79 \pm 0.47^{\mathrm{b}}$ & $55.40 \pm 0.616^{\mathrm{b}}$ \\
SL & $58.09 \pm 0.39^{\mathrm{c}}$ & $57.93 \pm 3.56^{\mathrm{b}}$ \\
\hline
\end{tabular}

$\mathrm{EC}_{50}\left(\mu \mathrm{gmL}^{-1}\right)$ expressed in $\mu \mathrm{g}$ of extract $/ \mathrm{mL}$ of DPPH; (mM) Values expressed in millimolar of trolox per $\mathrm{g}$ of extract; (YL) Young Leaves; (AL) Adult Leaves; (SL) Senescent Leaves. Values with different letters demonstrate statistical diffrence $(\mathrm{p}<0.05)$.

Table 7. Correlation between the presence of phenolic compounds and the antioxidant activity determined through the Pearson's correlation coefficient.

\begin{tabular}{|c|c|c|c|c|}
\hline & Phenols & Flavonoids & DPPH & ABTS \\
\hline & $\left(\mu g \mathbf{m L}^{-1}\right)$ & $\left(\mu \mathrm{gmL}^{-1}\right)$ & $\left(\mu \mathrm{gmL}^{-1}\right)$ & $(\mathrm{mM})$ \\
\hline Phenols ( $\left.\mu \mathrm{gmL}^{-1}\right)$ & 1 & & & \\
\hline Flavonoids $\left(\mu \mathrm{gmL}^{-1}\right)$ & 0.9358 & 1 & & \\
\hline DPPH $\left(\mu \mathrm{gmL}^{-1}\right)$ & -0.9468 & -0.8124 & 1 & \\
\hline ABTS (mM) & 0.5499 & 0.3394 & -0.5118 & 1 \\
\hline
\end{tabular}

Table 8. Growth inhibition of Staphylococcus aureus by ethanolic extracts obtained from leaves of Cordia glabrata.

\begin{tabular}{cccccccc}
\hline \multirow{2}{*}{ Sample } & \multicolumn{7}{c}{ Growth inhibition (\%) } \\
\cline { 2 - 8 } & $\mathbf{6 2 . 5}$ & $\mathbf{1 2 5}$ & $\mathbf{2 5 0}$ & $\mathbf{5 0 0}$ & $\mathbf{1 0 0 0}$ & $\mathbf{2 0 0 0}$ & MIC \\
\hline \multirow{2}{*}{ AL } & $\mu g \mathrm{gL}^{-1}$ & $\mu g \mathrm{gL}^{-1}$ & $\mu \mathrm{gmL}^{-1}$ & $\mu \mathrm{gmL}^{-1}$ & $\mu \mathrm{gmL}^{-1}$ & $\mu \mathrm{gmL}^{-1}$ & $\mu \mathrm{gmL}^{-1}$ \\
& $5.7 \pm 0.0$ & $10.9 \pm 0.0$ & $12.3 \pm 2.3$ & $14.3 \pm 0.3$ & $33.8 \pm 3.4$ & $100.0 \pm 5.2$ & 2000 \\
\hline
\end{tabular}

(AL) Adult Leaves extract; (MIC) Minimum inhibitory concentration.

Table 9. Cytotoxicity and potential antiviral and virucidal activity of $C$. glabrata adult leaves extract against Herpes Simplex Virus type 2 (HSV-2) strain 333.

\begin{tabular}{cccc}
\hline Sample & $\mathbf{C C}_{\mathbf{5 0}}$ & \% of inhibition & CV $_{\mathbf{5 0}}$ \\
\hline & $\mu \mathrm{gmL}^{-1}$ & & $\mu_{\mathrm{gmL}^{-1}}$ \\
$\mathbf{A L}$ & $87.43 \pm 17.26$ & $29.98 \pm 5.82$ & $<0.195$ \\
Aciclovir $^{\mathrm{a}}(\mathbf{1 5} \mu \mathbf{M})$ & - & 100 & - \\
\hline
\end{tabular}

$\mathrm{CC}_{50=} 50 \%$ cytotoxic concentration; $\mathrm{CV}_{50=} 50 \%$ virucidal concentration; $\left({ }^{*}\right)$ maximum percentage of inhibition of HSV-2 viral replication at the maximum non-toxic concentration $\left(50 \mathrm{\mu gmL}^{-1}\right)$ tested; ( $\left.{ }^{\mathrm{a}}\right)$ positive control of HSV-2 replication inhibition. 


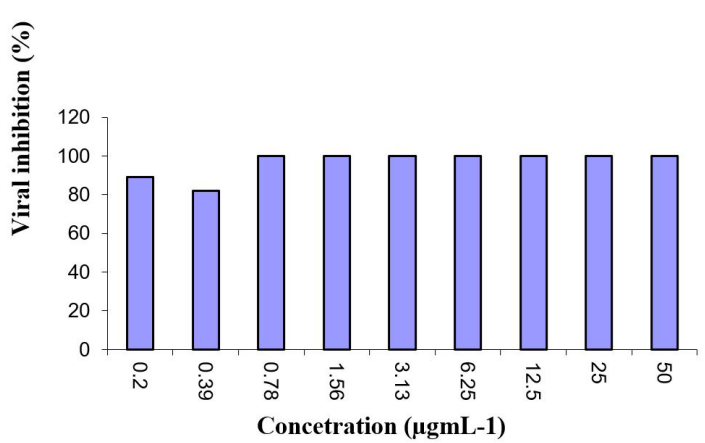

Figure 1. Results of the evaluation of the C. glabrata extract virucidal activity against HSV-2 strain 333 by the plate reduction assay. Percentages of viral inhibition were determined in comparison to controls.

\section{Discussion}

The species $C$. glabrata is abundant in the Cerrado (Brazilian Savannah) region of Mato Grosso and presents different phenophases: during the rain season, young and adult leaves are observed, and in the dry season, the presence of senescent leaves. In the dry season, the presence of flowers can be observed (Lorenzi, 1992; Melo and Lyra-Lemos, 2008).

The yield difference observed between the different leaves can be explained by the variation, mainly, in the content of chlorophyll and other metabolites present in the different phenophases of the plant material, since during the phenological development of a plant the concentration of metabolites in its tissues is variable during each period, as it happens with chlorophyll, which according to Streit et al. (2005) are found in nature in approximate proportions of $3: 1$. In the development of a plant, lower chlorophyll levels are observed in young leaves with a progressive increase during its maturing process, reaching a plateau during its adult phase. With the senescence of the leaves, chlorophyll and other metabolites, such as carotenoids, are reabsorbed so that biological recycling can happen, directing these metabolites to other plant tissues. (Maia and Piedade, 2002; Sousa et al., 2015).

The metabolites observed in the phytochemical screening of $C$. glabrata corroborate with reports from other authors that evidenced the presence of these metabolites in species from the Cordia genus (Matias et al., 2015). Phenolic compounds are commonly found in the plantae kingdom and are important due to their different biological activities such as antioxidant, anti-inflammatory, antimicrobial, antiviral and photoprotective (Nicácio et al., 2017).

Prabu et al. (2018) worked with methanolic extracts from Cordia diffusa leaves and found values of $5.03 \pm 0.50 \mu \mathrm{gmL}^{-1}$ for phenolic compounds and $5.65 \pm$ $0.43 \mu \mathrm{gmL}^{-1}$ for flavonoids, while Santi et al. (2014) found values of $79.48 \pm 0.63 \mathrm{mgEAG} \mathrm{g}^{-1}$ for phenols and $65.03 \pm$ $4.59 \mathrm{mgEQ} \mathrm{g}^{-1}$ for flavonoids in ethanolic extracts of $C$. verbenacea leaves. The results for $C$. glabrata were higher, with values from 17.13 to $26.04 \mu \mathrm{gmL}^{-1}$ of phenols and 5.85 to $10.30 \mu \mathrm{gmL}^{-1}$ for flavonoids. For phenols, the values obtained were 68.51 to 104.17 , in mgEAG g-1 $^{-1}$ and 3.90 to 6.86 of flavonoids, in mgEQ $\mathrm{g}^{-1}$.

The quantified metabolites in C. glabrata were the ferulic acid, $p$-cumáric acid and caffeic acid, as already reported in other species of the genus Cordia, such as gallic and caffeic acid found in C. verbenacea (Matias et al., 2015), ferulic acid in C. diffusa, (Prabu et al., 2018), quercetin and apigenin in C. dichotoma, (Rahman and Akhtar, 2016) and kaempferol in C. sinensis (Al-Musayeib et al., 2011). According to some authors, it is suggested that gallic acid, ferulic acid, p-cumaric acid, caffeic acid, quercetin, and apigenin have a direct role in antioxidant, antiviral, antimicrobial, and photoprotective processes (Nicácio et al., 2017).

Greater amounts of palmitic acid, stearic acid, linoleic acid and myristic acid found in C. glabrata agrees with other authors who point out the presence of fatty acids in the genus Cordia as already described by Adeosun et al. (2015) who identified palmitic, oleic, linoleic, stearic, myristic, and palmitoleic acids, for the species Cordia sebestena, Cordia ecalyculata, Cordia myxa and Cordia sellowiana. The presence of fatty acids in the composition of plant extracts can be useful for the pharmaceutical, cosmetic, and food industries, among others, since several fatty acids reportedly present potential antioxidant, antiinflammatory, and antidepressant activities, besides helping to improve essential skin conditions (Mohd-Nasir and Mohd-Setapar, 2018).

During the different phenophases of the leaves, there was significant variation in the $\mathrm{EC}_{50}$ values provided by the DPPH radical scavenging method. The greater potential antioxidant activity found in the extract of adult leaves can be explained by the accumulation of metabolites produced during the growth process of this organ, with a subsequent decrease in senescent leaves, where the accumulated metabolites are reabsorbed by the plant to be reused (Maia and Piedade, 2002). From the DPPH and $\mathrm{ABTS}^{+}$data, it was possible to verify a tendency between the results of the methods, that is, even if different mechanisms of analysis were presented, the values obtained showed the same profile of potential antioxidant activity for the analyzed extracts (Gaber et al., 2021). The DPPH method has proven to be easier, of high precision and reproduction for the analysis of plant extracts and isolated compounds when compared to the $\mathrm{ABTS}^{+}$method, besides that, the radical DPPH reacts emphatically with polyphenols and $\mathrm{ABTS}^{+}$with a greater amount of phenolic compounds (Mareček et al., 2017).

Santi et al. (2014) performed the DPPH radical scavenging method with $C$. verbeneacea and found an $\mathrm{EC}_{50}$ value of $316.70 \pm 23.16 \mu \mathrm{gmL}^{-1}$, revealing a lower potential antioxidant activity when compared with the data described in this study for the species C. glabrata, which showed $\mathrm{EC}_{50}$ values between 49.79 to $58.09 \mu \mathrm{gmL}^{-1}$.

Thus, when comparing $C$. glabrata with other species of the genus, its potential antioxidant activity in vitro is higher.

When Pearson's correlation was performed between the results from phenolic compounds, flavonoids, and potential antioxidant activity by the DPPH and ABTS $^{+}$ methods assays, a direct correlation was observed between the concentration of phenolic and flavonoid compounds, and between the $\mathrm{ABTS}^{+}$method and the phenolic and 
flavonoid compounds. An indirect correlation was found for the antioxidant activity by the DPPH method and the concentration of phenolic compounds, between DPPH and flavonoids, and between the two methods of antioxidant evaluation. The Strong positive correlation by Pearson's method found between the amount of phenolic compounds and flavonoids, shows that the increase in the concentration of phenolic compounds, directly reflects in the concentration increase of flavonoids. Unlike the DPPH free radical, $\mathrm{ABTS}^{+}$reacts with a greater amount of phenolic compounds, showing that the greater the spectrum of phenolic compounds, the greater the antioxidant activity observed. The moderate negative correlation observed between the $\mathrm{ABTS}^{+}$and DPPH methods pointed out the existence of an inversely proportional relationship between both tests.

The presence of metabolites in plant extracts with potential antioxidant activity arouses interest in research due to their photoprotective activity, since many of the metabolites that perform antioxidant activity are also responsible for protecting plant tissue against UV radiation (Lefahal et al., 2018; Nunes et al., 2018).

According to Brazilian law, Collegiate Board Resolution (RDC) № 30, of June 1, 2012 (Brasil, 2012), for a product to be able to play a photoprotective role, the SPF found must be equal to or greater than 6.0. Although the extracts did not have the minimum SPF value required by the Brazilian resolution to be considered as having a potential photoprotective effect, they can be associated with synthetic compounds, in order to promote a synergistic action and consequently increase the photoprotective activity, as well as decreasing possible unwanted effects of synthetic products.

The results obtained for an antimicrobial analysis, corroborate those presented by Bianco et al. (2017) which revealed that the extract of $C$. glabrata did not show antimicrobial activity against gram-positive microorganisms Streptococcus mutans and Streptococcus sobrinus. GaettiJardim Junior et al. (2009) also found no antimicrobial activity for extracts of $C$. glabrata against strains of gram-negative (Aggregatibacter actinomycetemcomitans, Fusobacterium nucleatum, Porphyromonas gingivalis, Prevotella intermedia and Pseudomonas aeruginosa) and gram-positive (Enterococcus faecalis and Streptococcus mutans) microorganisms.

The virucidal activity observed can be attributed mainly to phenolic and flavonoid compounds present in the extract (Özçelik et al., 2011). Acoording to Peter et al. (2017) caffeic acid and gallic acid present in propolis extracts have antiviral action, and Hochheim et al. (2019) when evaluating fractions enriched in phenolic and flavonoid compounds, have identified a potent anti-HSV activity, with evident virucidal effect. The direct inactivation of the viral particles (virucidal action) presented by the $C$. glabrata extract may be due to the denaturation of the viral capsid proteins of the viral envelope, which may be necessary for the adsorption of the HSV-2 virus in the cellular receptors and penetration into the host cell, as well as a possible damage to the structure of the virion (Suazo et al., 2015; Álvarez et al., 2020).
Studies with other species from the Cordia genus demonstrate antiviral activity, e.g. Cordia spinescens (Matsuse et al., 1999) against HIV and Cordia salicifolia (Hayashi et al., 1990) for anti-HSV activity. Thus, the ability of the extract to reduce the infectivity of HSV-2 in concentrations lower than its $\mathrm{CC}_{50}$ suggests that it is a promising candidate for incorporation into nanostructured systems, providing a possibility of use of the extract as a drug with virucidal action, and/or a viral inactivating agent in topical products, detergents and cosmetics.

\section{Conclusion}

The studies for the determination of the phytochemical profile showed the presence of flavonoids, tannins, and terpenes, in addition to the quantification of the phenolic acids: caffeic, $p$-cumaric, and ferulic, by UPLC-MS/MS. The CG-MS analysis showed that palmitic acid is the main fatty acid present in the extract, followed by stearic acid, linoleic acid, and myristic acid. The extracts showed a potential photoprotective action and can be associated with synthetic compounds in order to reduce these compounds, which are often responsible for allergenic processes.

The adult leaves extracts obtained from C. glabrata had superior biological activities in vitro (antioxidant and virucide) when compared to other species from the same genus. Thus, the data revealed in this article show promise for the isolation of $C$. glabrata compounds in order to use them in cosmetic and/or pharmaceutical products in their isolated form or as a standardized crude extract, in addition to adding value to the flora of the Cerrado (Brazilian Savannah) region of Mato Grosso.

\section{Acknowledgements}

This study was financed in part by the Coordenação de Aperfeiçoamento de Pessoal de Nível Superior - Brasil (CAPES) Finance Code 001, and the Financiadora de Estudos e Projetos (FINEP) (agreement 2013: 01.13.0434.00, ref. 0645/13). The authors would like to thank the Federal University of Mato Grosso (UFMT) for the infrastructure provided for the research. They are also grateful for the support of the Empresa Brasileira de Pesquisa Agropecuária (EMBRAPA Agrossivipastoril) for the kindness of carrying out analyzes in UPLC-MS/MS for the quantification of phenolic compounds.

\section{References}

ADEOSUN, C.B., BAMIGBADE, O.I., OSHO, A. and ATOLANI, O., 2015. Volatile Composition of the Leaf, Flower and Fruit of Cordia sebestena (L.).Journal of Essential Oil Bearing Plants, vol. 18, no. 4, pp. 976-981. http://dx.doi.org/10.1080/0972060X.2014.884758.

AL-MUSAYEIB, N., PERVEEN, S., FATIMA, I., NASIR, M. and HUSSAIN, A., 2011. Antioxidant, anti-glycation and anti-inflammatory activities of phenolic constituents from Cordia sinensis. Molecules (Basel, Switzerland), vol. 16, no. 12, pp. 10214-10226. http:// dx.doi.org/10.3390/molecules161210214. PMid:22158590. 
ÁlVAREZ, D.M., CASTILLO, E., DUARTE, L.F., ARRIAGADA, J., CORRALES, N., FARÍAS, M.A., HENRÍQUEZ, A., AGURTO-MUÑOZ, C. and GONZÁLEZ, P.A., 2020. Current Antivirals and Novel Botanical Molecules Interfering With Herpes Simplex Virus Infection. Frontiers in Microbiology, vol. 11, p. 139. http://dx.doi. org/10.3389/fmicb.2020.00139. PMid:32117158.

BAYEUX, M.C., FERNANDES, A.T., FOGLIO, M.A. and CARVALHO, J.E., 2002. Evaluation of the antiedematogenic activity of artemetin isolated from Cordia curassavica DC. Brazilian Journal of Medical and Biological Research, vol. 35, no. 10, pp. 12291232. http://dx.doi.org/10.1590/S0100-879X2002001000017. PMid:12424497.

BIANCO, K.G., GAETTI-JARDIM, E.C., BRIGHENTI, F.L. and GAETTIJARDIM JÚNIOR, E., 2017. Evaluation of antimicrobial activity of plant extracts from Brazilian savanna on cariogenic cocci. Archives of Health Investigation, vol. 6, no. 4. http://dx.doi. org/10.21270/archi.v6i4.1829.

BOTREL, P.P., PINTO, J.E.B.P., FERRAZ, V., BERTOLUCCI, S.K.V. and FIGUEIREDO, F.C., 2010. Teor e composição química do óleo essencial de Hyptis marrubioides Epl., Lamiaceae em função da sazonalidade. Acta Scientiarum. Agronomy, vol. 32, no. 3, pp. 533-538. http://dx.doi.org/10.4025/actasciagron.v32i3.3415.

BRASIL, 2012. Resolução - RDC $N^{\circ} 30$, de 1 de Junho de 2012. Diário Oficial da República Federativa do Brasil, Brasília.

BURLESON, F.G., CHAMBERS, T.M. and WIEDBRAUK, D.L., 1992. Virology: a laboratory manual. Cambridge: Academic Press.

CLINICAL AND LABORATORY STANDARDS INSTITUTE - CLSI, 2018. M07: methods for dilution antimicrobial susceptibility tests for bacteria that grow aerobically. Wayne: CLSI, vol. 38, no. 2, 90 p.

CLINICAL AND LABORATORY STANDARDS INSTITUTE - CLSI, 2020. M100: performance standards for antimicrobial susceptibility testing. Wayne: CLSI, vol. 40, no. 1, 293 p.

GABER, N.B., EL-DAHY, S.I. and SHALABY, E.A., 2021. Comparison of ABTS, DPPH, permanganate, and methylene blue assays for determining antioxidant potential of successive extracts from pomegranate and guava residues. Biomass Conversion and Biorefinery, https://doi.org/10.1007/s13399-021-01386-0.

GAETTI-JARDIM JUNIOR, E., LANDUCCI, L.F., GAETTI-JARDIM, E.C., SANGALLI, J., and SOUSA, F.R.N., 2009. Atividade inibitória de extratos do cerrado brasileiro sobre microrganismos anaeróbios e associados a infecções nosocomiais. Revista Brasileira de Ciências da Saúde, vol. 13, no. 2, pp. 43-52.

HAYASHI, K., HAYASHI, T., MORITA, N. and NIWAYAMA, S., 1990. Antiviral activity of an extract of Cordia salicifolia on herpes simplex virus type 1. Planta Medica, vol. 56, no. 5, pp. 439-443. http://dx.doi.org/10.1055/s-2006-961006. PMid:1963951.

HECKMAN, C.W., 1998. The Pantanal of Poconé. Biota and Ecology in the Northern Section of the World's Largest Pristine Wetland In H.J. DUMONT, ed. Monographiae biologicae. Netherlands, Dordrecht: Springer Natural. https://doi.org/10.1007/97894-017-3423-3.

HOCHHEIM, S., GUEDES, A., FACCIN-GALHARDI, L., RECHENCHOSKI, D.Z., NOZAWA, C., LINHARES, R.E., SILVA FILHO, H.H., RAU, M., SIEBERT, D.A., MICKE, G. and CORDOVA, C.M.M., 2019. Determination of phenolic profile by HPLC-ESI-MS/MS, antioxidant activity, in vitro cytotoxicity and anti-herpetic activity of propolis from the Brazilian native bee Melipona quadrifasciata. Revista Brasileira de Farmacognosia, vol. 29, no. 3, pp. 339-350. http://dx.doi.org/10.1016/j.bjp.2018.12.010.

INTERNATIONAL PLANT NAMES INDEX - IPNI, 1845. [viewed 28 January 2020]. Cordia glabrata A.DC. [online]. Australian: IPNI. Available from: https://www.ipni.org/n/274946-2
JARADAT, N., AL-LAHHAM, S., ABUALHASAN, M.N., BAKRI, A., ZAIDE, H., HAMMAD, J., HUSSEIN, F., ISSA, L., MOUSA, A. and SPEIH, R., 2018. Chemical constituents, antioxidant, cyclooxygenase inhibitor, and cytotoxic activities of Teucrium pruinosum Boiss. Essential Oil. BioMed Research International, vol. 2018, pp. 4034689. http://dx.doi.org/10.1155/2018/4034689. PMid:30151381.

JHAM, G.N., TELES, F.F.F. and CAMPOS, L.G., 1982. Use of aqueous $\mathrm{HCl} / \mathrm{MeOH}$ as esterification reagent for analysis of fatty acids derived from soybean lipids. Journal of the American Oil Chemists' Society, vol. 59, no. 3, pp. 132-133. http://dx.doi.org/10.1007/ BF02662261.

LAMEIRA, O.A., PINTO, J.E.B.P., ARRIGONI-BLANK, M. F. and CARDOSO, M., 1997. Efeito de compostos fenólicos, carvão ativado e do meio físico no desenvolvimento de segmento nodal de Cordia verbenacea L. Ciência Rural, vol. 27, no. 2, pp. 189-192. http:// dx.doi.org/10.1590/S0103-84781997000200003.

LEFAHAL, M., ZAABAT, N., AYAD, R., MAKHLOUFI, E., DJARRI, L., BENAHMED, M., LAOUER, H., NIETO, G. and AKKAL, S., 2018. In Vitro assessment of total phenolic and flavonoid contents, antioxidant and photoprotective activities of crude methanolic extract of aerial parts of Capnophyllum peregrinum (L.) Lange (Apiaceae) growing in Algeria. Medicines (Basel, Switzerland), vol. 5, no. 2, pp. 26. http://dx.doi.org/10.3390/medicines5020026. PMid:29565294.

LORENZI, H., 1992. Árvores brasileiras: manual de identificação e cultivo de plantas arbóreas nativas do Brasil. 7th ed. Nova Odessa, SP: Plantarum.

MAIA, L.A. and PIEDADE, M.T.F., 2002. Influência do pulso de inundação na fenologia foliar e conteúdo de clorofila em duas espécies da floresta de Igapó da Amazônia Central, Brasil. Acta Amazonica, vol. 32, no. 1, pp. 55-64. http://dx.doi. org/10.1590/1809-43922002321064.

MANSUR, J.S., BRENDER, M.N.R., MANSUR, M.C.A. and AZULAY, R.D., 1986. Determinação do fator de proteção solar por espectrofotometria. Anais Brasileiros de Dermatologia, vol. 61, no. 3, pp. 121-124.

MAREČEK, V., MIKYŠKA, A., HAMPEL, D., ČEJKA, P., NEUWIRTHOVÁ, J., MALACHOVÁ, A. and CERKAL, R., 2017. ABTS and DPPH methods as a tool for studying antioxidant capacity of spring barley and malt. Journal of Cereal Science, vol. 73, pp. 40-45. http://dx.doi.org/10.1016/j.jcs.2016.11.004.

MATIAS, E.F.F., ALVES, E.F., DO NASCIMENTO SILVA, M.K., DE ALENCAR CARVALHO, V.R., COUTINHO, H.D.M. and DA COSTA, J.G.M., 2015. The genus Cordia: botanists, ethno, chemical and pharmacological aspects. Brazilian Journal of Pharmacognosy, vol. 25, no. 5, pp. 542-552. http://dx.doi.org/10.1016/j. bjp.2015.05.012.

MATIAS, E.F.F., ALVES, E.F., SILVA, M.K.N., CARVALHO, V.R.A., MEDEIROS, C.R., SANTOS, F.A.V., BITU, V.C.N., SOUZA, C.E.S., FIGUEREDO, F.G., BOLIGON, A.A., ATHAYDE, M.L., COSTA, J.G.M. and COUTINHO, H.D.M., 2016. Potentiation of antibiotic activity of aminoglycosides by natural products from Cordia verbenacea DC. Microbial Pathogenesis, vol. 95, pp. 111-116. http://dx.doi. org/10.1016/j.micpath.2016.03.009. PMid:27033000.

MATSUSE, I.T., LIM, Y.A., HATTORI, M., CORREA, M. and GUPTA, M.P., 1999. A search for anti-viral properties in Panamanian medicinal plants. The effects on HIV and its essential enzymes. Journal of Ethnopharmacology, vol. 64, no. 1, pp. 15-22. http:// dx.doi.org/10.1016/S0378-8741(98)00099-3. PMid:10075118.

MELO, J.I.M. and LYRA-LEMOS, R.P., 2008. Sinopse taxonômica de Boraginaceae sensu lato A. Juss. no Estado de Alagoas, Brasil. Acta Botanica Brasílica, vol. 22, no. 3, pp. 701-710. http://dx.doi. org/10.1590/S0102-33062008000300008. 
MOHD-NASIR, H. and MOHD-SETAPAR, S.H., 2018. Natural ingredients in cosmetics from Malaysian plants: a review. Sains Malaysiana, vol. 47, no. 5, pp. 951-959. http://dx.doi. org/10.17576/jsm-2018-4705-10.

MOREIRA-ARAÚJO, R.S.D.R., BARROS, N.V.D.A., PORTO, R.G.C.L., BRANDÃO, A.C.A.S., DE LIMA, A., FETT, R., 2019. Bioactive compounds and antioxidant activity three fruit species from the Brazilian Cerrado. Revista Brasileira de Fruticultura, vol. 41, no. 3, pp. 1-8. https://doi.org/10.1590/0100-29452019011.

MOSMANN, T., 1983. Rapid colorimetric assay for cellular growth and survival: application to proliferation and cytotoxicity assays. Application to Proliferation and Cytotoxicity Assays., vol. 65, no. 1-2, pp. 55-63. PMid:6606682.

MOULIN, J.C., RODRIGUES, B.P., OLIVEIRA, J.T.D.S. and ROSA, R.A., 2016. Propriedades tecnológicas do lenho de louro-preto. Pesquisa Florestal Brasileira, vol. 36, no. 88, pp. 415-421. http:// dx.doi.org/10.4336/2016.pfb.36.88.994.

NEVES, L.C., ALENCAR, S.M., and CARPES, S.T., 2009. Determinação da atividade antioxidante e do teor de compostos fenólicos e flavonoides totais em amostras de pólen apícola de Apis mellifera. Brazilian Journal of Food Technology, vol. VII BMCFB, pp. 107-110.

NICÁCIO, A.E., ROTTA, E.M., BOEING, J.S., BARIZÃO, É.O., KIMURA, E., VISENTAINER, J.V. and MALDANER, L., 2017. Antioxidant activity and determination of phenolic compounds from Eugenia involucrata DC. fruits by UHPLC-MS/MS. Food Analytical Methods, vol. 10, no. 8, pp. 2718-2728. http://dx.doi.org/10.1007/ s12161-017-0840-3.

NUNES, A.R., VIEIRA, Í.G.P., QUEIROZ, D.B., LEAL, A.L.A.B., MAIA MORAIS, S., MUNIZ, D.F., CALIXTO-JUNIOR, J.T. and COUTINHO, H.D.M., 2018. Use of Flavonoids and Cinnamates, the Main Photoprotectors with Natural Origin. Advances in Pharmacological Sciences, vol. 2018, pp. 5341487. http://dx.doi. org/10.1155/2018/5341487. PMid:30622564.

ÖZÇELIK, B., KARTAL, M. and ORHAN, I., 2011. Cytotoxicity, antiviral and antimicrobial activities of alkaloids, flavonoids, and phenolic acids. Pharmaceutical Biology, vol. 49, no. 4, pp. 396-402. http:// dx.doi.org/10.3109/13880209.2010.519390. PMid:21391841.

PETER, C.M., PICOLI, T., ZANI, J.L., LATOSINSKI, G.S., LIMA, M., VARGAS, G.D.Á., HÜBNER, S.O. and FISCHER, G., 2017. Atividade antiviral e virucida de extratos hidroalcoólicos de própolis marrom, verde e de abelhas Jataí (Tetragonisca angustula) frente ao herpersvírus bovino tipo 1 (BoHV-1) e ao vírus da diarreia viral bovina (BVDV). Pesquisa Veterinária Brasileira, vol. 37, no. 7, pp. 667-675. http://dx.doi.org/10.1590/s0100$736 \times 2017000700003$.

PINHO, L., SOUZA, P.N.S., MACEDO SOBRINHO, E., ALMEIDA, A.C. and MARTINS, E.R., 2012. Atividade antimicrobiana de extratos hidroalcoolicos das folhas de alecrim-pimenta. Ciência Rural, vol. 42, no. 2, pp. 323-331. http://dx.doi.org/10.1590/S010384782012005000003 .

PIRES, J., TORRES, P.B., SANTOS, D.Y.A.C. and CHOW, F. 2017. Ensaio em microplaca do potencial antioxidante através do método de sequestro do radical livre DPPH para extratos de algas. São Paulo: Universidade de São Paulo, Instituto de Biociências, 6 p. Comunicado técnico.

PRABU, K., RAJASEKARAN, A., BHARATHI, D., and RAMALAKSHMI, S., 2018. Anti-oxidant activity, phytochemical screening and HPLC profile of rare endemic Cordia diffusa. Journal of King Saud University - Science, vol. 31, no. 4, pp. 724-727. https:// doi.org/10.1016/j.jksus.2018.04.025.

RAHMAN, M.A. and AKHTAR, J., 2016. Phytochemistry and pharmacology of traditionally used medicinal plant Cordia dichotoma Linn (Boraginaceae). Current Trends in Biotechnology and Pharmacy, vol. 10, no. 2, pp. 186-193.

ROESLER, R., MALTA, L.G., CARRASCO, L.C., HOLANDA, R.B., SOUSA, C.A.S. and PASTORE, G.M., 2007. Atividade antioxidante de frutas do cerrado. Food Science and Technology (Campinas), vol. 27, no. 1, pp. 53-60. http://dx.doi.org/10.1590/S010120612007000100010.

RUFINO, M.S.M., ALVES, R.E., BRITO, E.S., MORAIS, S.M., SAMPAIO, C.G., PÉREZ-JIMÉNEZ, J., SAURA-CALIXTO, F.D., 2007. Metodologia científica: determinação da atividade antioxidante total em frutas pela captura do radical livre ABTS Fortaleza, CE: Embrapa Agroindústria Tropical, 4 p. Comunicado técnico, no. 128.

SALAZAR-ARANDA, R., PÉREZ-LÓPEZ, L.A., LÓPEZ-ARROYO, J., ALANÍS-GARZA, B.A. and WAKSMAN DE TORRES, N., 2011. Antimicrobial and antioxidant activities of plants from Northeast of Mexico. Evidence-Based Complementary and Alternative Medicine, vol. 2011, pp. 1-6. http://dx.doi.org/10.1093/ecam/ nep127. PMid:19770266.

SANTI, M.M., SANCHES, F.S., SILVA, J.F.M. and SANTOS, P.M.L., 2014. Determinação do perfil fitoquímico de extrato com atividade antioxidante da espécie medicinal Cordia verbenacea DC. por HPLC-DAD. Revista Brasileira de Plantas Medicinais, vol. 16, no. 2, pp. 256-261. http://dx.doi.org/10.1590/S151605722014000200014.

SILVA, N.L., ARAÚJO, Í.P.C., BATISTA, M.R.F., SANTOS, T.B.A., FERNANDO, W.L. and AMARAL, F.R., 2017. Determinação da atividade antioxidante e teor de flavonoides totais equivalentes em quercetina em folhas de Cymbopogon citratus (d.c.) stapf e Melissa officinalis lam. Conexão Ciência (Online), vol. 12, no. 1, pp. 46-53. http://dx.doi.org/10.24862/cco.v12i1.499.

SIMÕES, C.M.O., SCHENKEL, E.P., GOSMANN, G., DE MELLO, J.C.P., MENTZ, L.A. and PETROVICK, P.R., 2010. Farmacognosia: da planta ao medicamento. 6th ed. Porto Alegre: Editora da UFSC.

SOUSA, R., CARVALHO, M., DOROTEIA SILVA, M., GOMES, S., GUIMARAES, W. and ARAUJO, A., 2015. Leituras de clorofila e teores de $\mathrm{N}$ em fases fenológicas do milho. Colloquium Agrariae, vol. 11, no. 1, pp. 57-63. http://dx.doi.org/10.5747/ ca.2015.v11.n1.a118.

STREIT, N.M., CANTERLE, L.P., CANTO, M.W. and HECKTHEUER, L.H.H., 2005. As clorofilas. Ciência Rural, vol. 35, no. 3, pp. 748755. http://dx.doi.org/10.1590/S0103-84782005000300043.

SUAZO, P.A., TOGNARELLI, E.I., KALERGIS, A.M. and GONZÁLEZ, P.A., 2015. Herpes simplex virus 2 infection: molecular association with HIV and novel microbicides to prevent disease. Medical Microbiology and Immunology, vol. 204, no. 2, pp. 161-176. http://dx.doi.org/10.1007/s00430-014-0358-x. PMid:25209142.

TANASE, C., COSARCĂ, S. and MUNTEAN, D.L., 2019. A critical review of phenolic compounds extracted from the bark of woody vascular plants and their potential biological activity. Molecules (Basel, Switzerland), vol. 24, no. 6, pp. 1182. http:// dx.doi.org/10.3390/molecules24061182. PMid:30917556.

VIEIRA, D.D., MELO, J.I.M. and CONCEIÇÃO, A.S., 2015. Boraginales Juss. ex Bercht. \& J. Presl in the ecoregion Raso da Catarina, Bahia, Brazil. Biota Neotropica, vol. 15, no. 3, pp. 1-17. http:// dx.doi.org/10.1590/1676-0611-BN-2014-0201.

VIZZOTTO, M., KROLOW, A.C., and WEBER, G.E.B., 2010. Metabólitos secundários encontrados em plantas e sua importância. Pelotas: Embrapa Clima Temperado, 16 p. Embrapa Clima Temperado. Documentos, no. 316 .

WAGNER, H. and BLADT, S., 2001. Plant drug analysis: a thin layer chromatography atlas. 2nd ed. New York: The Cambridge Companion to Wittgenstein. 